\title{
Association between serum levels of caspase-cleaved cytokeratin-18 and early mortality in patients with severe spontaneous intracerebral hemorrhage
}

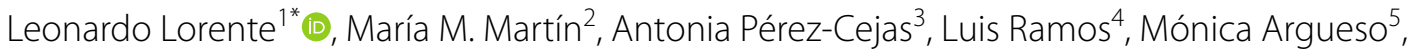
Jordi Solé-Violán ${ }^{6}$, Juan J. Cáceres ${ }^{7}$, Alejandro Jiménez ${ }^{8}$ and Victor García-Marín ${ }^{9}$

\begin{abstract}
Background: Apoptotic changes after cerebral hemorrhage in brain samples of humans have been found. Caspasecleaved cytokeratin (CCCK)-18 could be detected in the bloodstream during apoptosis. Higher circulating CCCK-18 levels have been associated with 6-month mortality in patients with basal ganglia hemorrhage. The aim of our study was to determine whether there is an association between serum CCCK-18 levels and early mortality of spontaneous intracerebral hemorrhage $(\mathrm{SIH})$ patients. We performed an observational, prospective and multicentre study. There were included patients with severe SIH defined as Glasgow Coma Scale (GCS) lower than 9. We determined serum CCCK-18 levels at the severe SIH diagnosis moment.
\end{abstract}

Results: We found that non-surviving SIH patients $(n=46)$ showed lower GCS, and higher serum CCCK-18 levels and APACHE-II score than survivor ones $(n=54)$. In ROC analysis was found that the area under the curve of serum CCCK-18 levels for 30-day mortality prediction was 90\% (95\% Cl 82-95\%; $\mathrm{p}<0.001)$. In the multiple logistic regression analysis, we found an association between serum CCCK-18 levels and 30-day mortality (OR 1.034; 95\% Cl 1.013-1.055; $\mathrm{p}=0.002$ ).

Conclusions: The novel finding of our study was that there is an association between high serum CCCK-18 levels and 30-day mortality in severe SIH patients.

Keywords: Caspase-cleaved cytokeratin-18, Spontaneous intracerebral hemorrhage, Patients, Mortality

\section{Introduction}

Spontaneous intracerebral hemorrhage $(\mathrm{SIH})$ results in a large amount of deaths, disabilities, and resource consumption [1-3]. Cell death by apoptosis occurs in cerebral hemorrhage [4-7]. Primary damage is caused by the effect of hematoma leading to disruption and mechanical deformation of cellular architecture. Secondary damage is induced by mitochondrial dysfunction, microglia activation and the release of neurotransmitter and inflammatory mediators; and those events lead to necrosis and to

\footnotetext{
*Correspondence: lorentemartin@msn.com

${ }^{1}$ Intensive Care Unit, Hospital Universitario de Canarias, Ofra, s/n, La Laguna, 38320 Santa Cruz de Tenerife, Spain

Full list of author information is available at the end of the article
}

the occurrence of programmed cell death by apoptosis [4-7].

Between 1999 and 2005 in some animals models were found the presence of apoptosis after cerebral hemorrhage [8-11]. In those studies with rats and rabbits using the terminal deoxynucleotidyl transferase (TdT)mediated deoxyuridine (dUTP)-biotin nick end labeling (TUNEL) were found cells undergoing DNA fragmentation in the striatum and in deep white matter in the frontal lobe; and those cells were mostly neurons and astrocytes in the center and periphery of cerebral hemorrhage [8-11]. Afterwards, apoptotic changes after cerebral hemorrhage in human brain samples have been found in several studies from 2003, and included 
TUNEL-positive cells and an increase of caspase-3 expression [12-18].

Cytokeratins (CK) family is a group of proteins distributed mainly in the epithelial tissue. Until now are known 20 types, named CK-1 to CK-20. CK-18 is cleaved by the action of caspases during apoptosis, then caspase-cleaved cytokeratin (CCCK)-18 appears and could be detected in the bloodstream $[19,20]$.

Higher circulating CCCK-18 levels have been found in patients with sepsis [21-25], liver diseases [26-30], and tumoral diseases [31, 32]. Besides, higher circulating CCCK-18 levels have been associated with a poor prognosis in patients with cerebral process, such as traumatic brain injury [33], aneurysmal subarachnoid hemorrhage [34] and basal ganglia hemorrage [35]. In the study by $\mathrm{Gu}$ et al. of patients with basal ganglia hemorrage was found an association between circulating CCCK-18 levels and 6-month mortality [35]. The aim of our study was to determine whether there is an association between serum CCCK-18 levels and early mortality of SIH patients.

\section{Methods \\ Design and subjects}

This multicentre, observational and prospective study was carried in six Intensive Care Units from Spain after the Institutional Review Board approval of all participating hospitals and with the written consent of patient guardians. Participating hospitals were the following: $\mathrm{H}$. Clínico Universitario de Valencia (Valencia), H. Universitario Nuestra Señora de Candelaria (Tenerife), H. General de La Palma (La Palma), H. Universitario de Canarias (Tenerife), H. Insular (Gran Canaria), H. Universitario Dr. Negrín (Gran Canaria).

We included patients with severe supratentorial SIH. We used Glasgow Coma Scale (GCS) [36] to classify SIH severity; and we considered severe SIH when $\mathrm{GCS} \leq 8$. Exclusion criteria were infratentorial or traumatic hemorrhage, inflammatory or malignant disease, hemorrhagic transformation of cerebral infarction, age $<18$ years, and pregnancy.

\section{Variables recorded}

The following variables were recorded for each patient: sex, site and cause of SIH, volume of SIH, presence of intraventricular hemorrhage or hydrocephalus, midline shift, evacuation of $\mathrm{SIH}$, age, sodium, temperature, platelets, pressure of arterial oxygen ( $\mathrm{paO} 2)$, fraction of inspired oxygen (FIO2), international normalised ratio (INR), fibrinogen, activated partial thromboplastin time (aPTT), lactic acid, GCS, creatinine, glycaemia, Acute Physiology and Chronic Health Evaluation II (APACHE II) score [37]. The end-point study was mortality at 30 days after severe SIH diagnosis.

\section{Blood sample collection and serum CCCK-18 analysis}

We collected serum blood samples when severe $\mathrm{SIH}$ was diagnosed to determine serum CCCK-18 levels. We determined serum CCCK-18 levels at the Laboratory Department of the Hospital Universitario de Canarias (Tenerife, Spain) by an enzyme-linked immunosorbent assay (ELISA). The kit used was M30 Apoptosense ${ }^{\circledR}$ ELISA kit (PEVIVA AB, Bromma, Sweden), and its intra-assay coefficient of variation $(\mathrm{CV})$, inter-assay $\mathrm{CV}$, and detection limit assay were $<10,<10 \%$ and $25 \mathrm{u} / \mathrm{L}$, respectively.

\section{Statistical methods}

We reported continuous and categorical variables as medians (with interquartile ranges) and frequencies (with percentages) respectively. We compared continuous and categorical variables between groups by means of Wilcoxon-Mann-Whitney test and Chi square test respectively. We used multiple logistic regression analysis to determine the association of serum CCCK-18 levels with 30-day mortality, after controlling for GCS, midline shift, age, intraventricular hemorrhage, and volume of intracerebral hemorrhage. Odds Ratio and its 95\% confidence intervals $(\mathrm{CI})$ were calculated to estimate the impact of each predictor variable. A receiver operating characteristic (ROC) analysis was carried out to determine the capacity of 30 day-mortality prediction by serum CCCK18 levels. We made 30 day-mortality Kaplan-Meier curves of SIH patients with higher/lower serum CCCK18 levels than $156 \mathrm{u} / \mathrm{L}$ (due to that those serum CCCK-18 levels were the optimal prognostic cut-off, for sensitivity and specificity, according to Youden J index). Each $p$ value lower than 0.05 was considered as statistically significant. We performed statistical analyses by SPSS 17.0 (SPSS Inc., Chicago, IL, USA), LogXact 4.1, (Cytel Co., Cambridge, MA), and NCSS 2000 (Kaysville, Utah).

\section{Results}

Of the 100 patients with severe $\mathrm{SIH}$, a total of 54 patients were alive at 30 days and 46 patients died during the first 30 days of SIH diagnosis. We did not find statistically significant differences between patient groups (non-surviving and surviving) in sex, site of $\mathrm{SIH}$, cause of $\mathrm{SIH}$, intraventricular hemorrhage, hydrocephalus, $\mathrm{SIH}$ evacuation, sodium, temperature, sodium, PaO2/FI02 ratio, platelets, INR, lactic acid, fibrinogen, creatinine, and aPTT. However, we found that non-surviving $\mathrm{SIH}$ patients showed lower GCS, and higher serum CCCK18 levels, APACHE-II score, age, volume of SIH, midline shift, and glycemia than survivor ones (Table 1).

We found the following correlations between serum CCCK-18 levels and age $(r h o=0.19 ; \mathrm{p}=0.053), \mathrm{SIH}$ volume $(\mathrm{rho}=0.26 ; \mathrm{p}=0.02)$, midline shift $(\mathrm{rho}=0.19$; 
Table 1 Clinical and biochemical characteristics of 30-day surviving and non-surviving patients with spontaneous intracerebral hemorrhage (SIH)

\begin{tabular}{|c|c|c|c|}
\hline & $\begin{array}{l}\text { Survivors } \\
(n=54)\end{array}$ & $\begin{array}{l}\text { Non-survivors } \\
(n=46)\end{array}$ & P value \\
\hline Gender female—n (\%) & $17(31.5)$ & $17(37.0)$ & 0.67 \\
\hline Site of $\mathrm{SIH} — \mathrm{n}(\%)$ & & & 0.81 \\
\hline Lobar & $41(75.9)$ & $33(71.7)$ & \\
\hline Basal ganglia & $3(5.6)$ & $4(8.7)$ & \\
\hline Thalamus & $5(9.3)$ & $3(6.5)$ & \\
\hline Periventricular & $5(9.3)$ & $6(13.0)$ & \\
\hline Cause of $\mathrm{SIH}-\mathrm{n}(\%)$ & & & 0.07 \\
\hline Hypertension & $37(68.5)$ & $30(65.2)$ & \\
\hline Amyloid angiopathy & $2(3.7)$ & $4(8.7)$ & \\
\hline Aneurysm & $3(5.6)$ & 0 & \\
\hline Arteriovenous malformation & $5(9.3)$ & 0 & \\
\hline OAT in therapeutic range & $3(5.6)$ & $6(13.0)$ & \\
\hline OAT out of therapeutic range & $3(5.6)$ & $6(13.0)$ & \\
\hline Fibrinolytic treatment & $1(1.9)$ & 0 & \\
\hline $\begin{array}{l}\text { Intraventricular hemorrhage- } \\
\text { n (\%) }\end{array}$ & $17(31.5)$ & $23(50.0)$ & 0.07 \\
\hline Hydrocephalus—n (\%) & $21(38.9)$ & $26(56.5)$ & 0.11 \\
\hline Evacuation $\mathrm{SIH}-\mathrm{n}(\%)$ & $18(33.3)$ & 9 (19.6) & 0.18 \\
\hline Age (years) — median (p 25-75) & $59(52-67)$ & $68(57-74)$ & 0.006 \\
\hline $\begin{array}{l}\text { Volume of SIH (cc) — median } \\
\text { (p 25-75) }\end{array}$ & $38(17-62)$ & 68 (29-99) & 0.02 \\
\hline $\begin{array}{l}\text { Midline shift (mm) - median } \\
\text { (p 25-75) }\end{array}$ & $1(0-7)$ & $5(0-11)$ & 0.005 \\
\hline $\begin{array}{l}\text { Sodium }(\mathrm{mEq} / \mathrm{L}) \text { - median ( } \mathrm{p} \\
25-75)\end{array}$ & $139(137-142)$ & $139(135-143)$ & 0.93 \\
\hline $\begin{array}{l}\text { Temperature }\left({ }^{\circ} \mathrm{C}\right) \text { - median }(\mathrm{p} \\
25-75)\end{array}$ & $36.9(36.0-37.4)$ & $36.5(35.0-37.0)$ & 0.10 \\
\hline$\underset{25-75)}{\mathrm{PaO} 2 / \mathrm{FIO}_{2} \text { ratio-median ( } \mathrm{p}}$ & $270(189-350)$ & $289(215-397)$ & 0.40 \\
\hline $\begin{array}{l}\text { Platelets_median*1 } 10^{3} / \mathrm{mm}^{3} \\
\text { (p 25-75) }\end{array}$ & $193(145-252)$ & $198(159-270)$ & 0.57 \\
\hline INR—median (p 25-75) & $1.10(1.00-1.31)$ & $1.14(1.02-1.87)$ & 0.34 \\
\hline $\begin{array}{l}\text { Lactic acid (mmol/L)-median } \\
\quad(\text { p 25-75) }\end{array}$ & $1.70(1.00-2.51)$ & $1.80(1.30-2.55)$ & 0.23 \\
\hline GCS score-median (p 25-75) & $8(6-8)$ & $4(3-6)$ & $<0.001$ \\
\hline $\begin{array}{l}\text { Glycemia (g/dL) — median (p } \\
\text { 25-75) }\end{array}$ & $141(118-190)$ & $170(141-216)$ & 0.01 \\
\hline aPTT (s)—median (p 25-75) & $29(27-32)$ & $30(24-34)$ & 0.68 \\
\hline $\begin{array}{l}\text { Fibrinogen (mg/dl)_-median } \\
\quad(\text { p 25-75) }\end{array}$ & $390(280-493)$ & $382(350-510)$ & 0.34 \\
\hline $\begin{array}{l}\text { APACHE-II score-median ( } p \\
\text { 25-75) }\end{array}$ & $18(14-20)$ & $24(20-26)$ & $<0.001$ \\
\hline $\begin{array}{l}\text { Creatinine (mg/dl) - median } \\
\quad(\text { p 25-75) }\end{array}$ & $0.77(0.68-0.90)$ & $0.80(0.60-1.01)$ & 0.36 \\
\hline $\begin{array}{l}\text { CCCK-18 (u/L)-median ( } p \\
\text { 25-75) }\end{array}$ & $129(112-177)$ & $291(212-341)$ & $<0.001$ \\
\hline
\end{tabular}

P 25-75 25th-75th percentile, OAT oral anticoagulant treatment, $\mathrm{PaO}_{2}$ pressure of arterial oxygen/fraction inspired oxygen, $\mathrm{FIO}_{2}$ pressure of arterial oxygen/ fraction inspired oxygen, INR international normalized ratio, GCS Glasgow Coma Scale, aPTT activated partial thromboplastin time, APACHE II Acute Physiology and Chronic Health Evaluation, CCCK caspase-cleaved cytokeratin $\mathrm{p}=0.10), \quad$ GCS $\quad(\mathrm{rho}=-0.29 ; \mathrm{p}=0.003)$, APACHE-II score $($ rho $=0.32 ; \mathrm{p}=0.001)$. We have not found statistically significant differences in serum CCCK-18 levels in patients with or without intraventricular hemorrhage $(\mathrm{p}=0.13)$, hydrocephalus $(\mathrm{p}=0.11)$ or evacuation of $\mathrm{SIH}$ $(\mathrm{p}=0.85)$.

We found the following area under the curve for 30-day mortality prediction: serum CCCK-18 levels of $90 \%$ (95\% CI 82-95\%; p < 0.001) (Fig. 1), age of $72 \%$ (95\% CI 60-82\%; $\mathrm{p}=0.004), \mathrm{SIH}$ volume of $68 \%$ (95\% CI $56-79 \% ; \mathrm{p}=0.02)$, midline shift of $68 \%(95 \%$ CI $55-78 \%$; $\mathrm{p}=0.003)$, GCS of $78 \%(95 \%$ CI $66-87 \% ; \mathrm{p}<0.001)$, APACHE-II score of $81 \%$ (95\% CI $69-89 \%$; $<<0.001$ ). We found the following differences in the comparisons in the area under the curve for 30-day mortality prediction between serum CCCK-18 levels and: age of $22 \%$ (95\% CI 9-34\%; p < 0.001), SIH volume of $25 \%$ (95\% CI $12-39 \%$; $<<0.001)$, midline shift of $26 \%$ (95\% CI $12-40 \%$; $\mathrm{p}<0.001)$, GCS of $16 \%(95 \%$ CI $3-29 \% ; \mathrm{p}=0.02)$, APACHE-II score of 13\% (95\% CI 1-26\%; $\mathrm{p}=0.046)$.

Kaplan-Meier 30-day survival analysis showed that patients with serum CCCK-18 levels higher than $156 \mathrm{u} / \mathrm{L}$ showed a higher mortality risk (Hazard ratio $=12.4 ; 95 \%$ CI 6.93-22.12; p <0.001) (Fig. 2).

In the multiple logistic regression analysis, we found an association between serum CCCK-18 levels and 30-day mortality $(\mathrm{OR}=1.034 ; 95 \%$ CI $1.013-1.055 ; \mathrm{p}=0.002)$ after to control for midline shift, GCS, SIH volume, intraventricular haemorrhage, and age (Table 2).

\section{Discussion}

The novel finding of our study was that there is an association between high serum CCCK-18 levels and 30-day mortality in severe SIH patients.

Previously, higher circulating CCCK-18 levels have been associated with 6-month mortality in patients with basal ganglia hemorrhage [35]. However, the association between high serum CCCK-18 levels and early SIH mortality found in our study is a novel finding. There are some differences between the study by Gu et al. [35] and our study. In the study by Gu et al. patients were included with basal ganglia hemorrhage [35], and our study included patients with supratentorial SIH at different locations (lobar, basal ganglia, thalamus and periventricular). In our study, patients with $\mathrm{SIH}$ and $\mathrm{GCS} \leq 8$ were included, and in the study by $\mathrm{Gu}$ et al., the clinical condition of severity was not used for the inclusion of patients. In the study by Gu et al. the end-point study was late mortality (at 6 months), and in our study our end-point was early mortality (at 30 days). The findings of our study are in consonance with those of other previous studies by our team, of patients with traumatic 


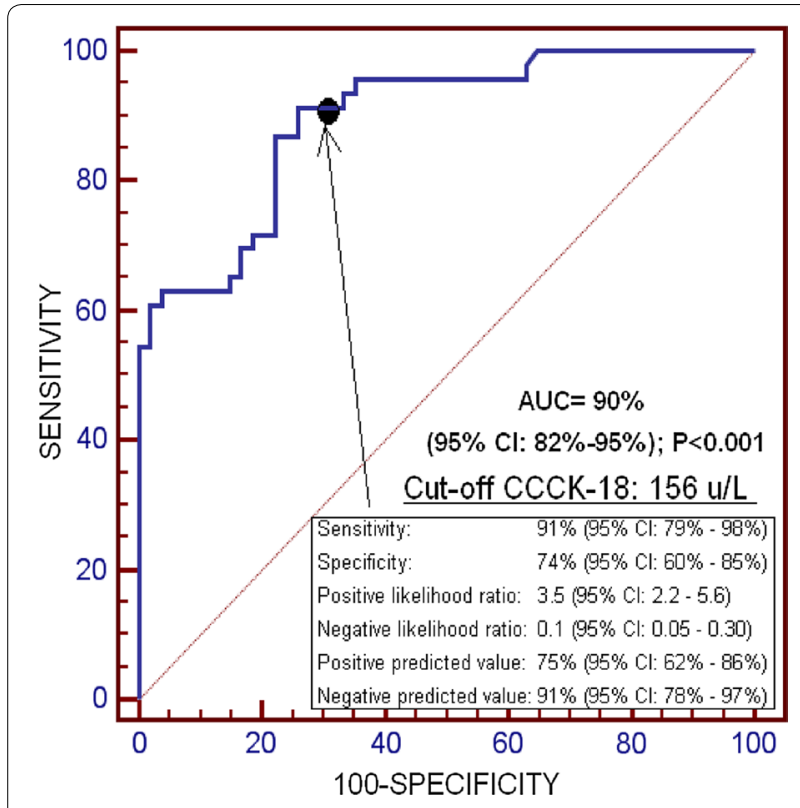

Fig. 1 Receiver operation characteristic analysis using serum caspase-cleaved cytokeratin (CCCK)-18 levels as predictor of mortality at 30 days

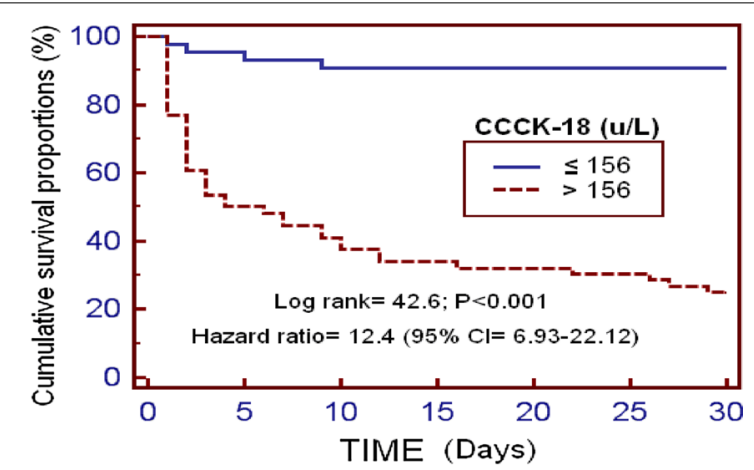

Number of patients at risk

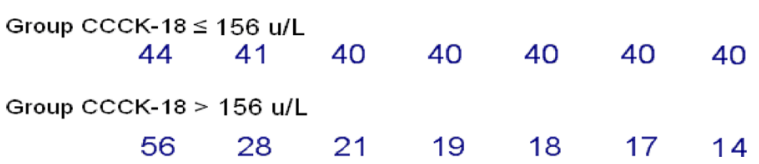

Fig. 2 Survival curves at 30 days using serum levels of caspasecleaved cytokeratin (CCCK)-18 higher or lower than $156 \mathrm{u} / \mathrm{L}$

brain injury, where we found an association between high serum CCCK-18 levels and 30-day mortality [33].

Our study presents some limitations. First, we do not report serum CCCK-18 concentrations in healthy controls; however, our objective study was to determine whether there is an association between serum CCCK-18 levels and SIH patient mortality and was not to determine whether SIH patients showed increased serum CCCK-18 levels. Second, there was not reported data about apoptosis in cerebral samples; however, our aim was to use
Table 2 Multiple logistic regression analysis to predict 30-day mortality

\begin{tabular}{llll}
\hline Variable & Odds ratio & $\begin{array}{l}\text { 95\% confi- } \\
\text { dence interval }\end{array}$ & $P$ \\
\hline Serum CCCK-18 levels (u/L) & 1.034 & $1.013-1.055$ & 0.002 \\
Glasgow Coma Scale (points) & 0.536 & $0.294-0.979$ & 0.04 \\
Midline shift (mm) & 1.139 & $0.935-1.387$ & 0.20 \\
Age (years) & 1.039 & $0.905-1.193$ & 0.59 \\
Volume of SIH (cc) & 1.003 & $0.975-1.031$ & 0.85 \\
Intraventricular hemorrhage (yes) & 1.136 & $0.133-9.727$ & 0.91 \\
\hline
\end{tabular}

CCCK caspase-cleaved cytokeratin

an easy technique to facilitate the reproduction by other researchers. Third, data about the evolution of circulating CCCK-18 concentrations in non-surviving and surviving patients during the evolution were not reported.

CCCK-18 is not a specific biomarker of brain apoptosis; thus, higher circulating CCCK-18 levels have been found in patients with sepsis [21-25], liver diseases [26-30], and tumoral diseases [31, 32]. However, serum CCCK-18 levels have been associated with mortality in patients with SIH in the study by Gu et al. [35] and in our study. The clinical utility of serum CCCK-18 levels for mortality prediction should be taken with caution; however, we think that could be considered as an additional biomarker in the prognostic prediction of $\mathrm{ICH}$ patients to other markers (as GSC, age, midline shift, volume of $\mathrm{SIH}$, or intraventricular hemorrhage). In addition, we found that serum CCCK-18 levels could be a better prognostic biomarker in $\mathrm{ICH}$ patients that age, SIH volume, midline shift, GCS, APACHE-II score according the area under the curve for 30-day mortality prediction of those variables.

Finally, the administration of antiapoptotic agents in SIH animal models have reduced cerebral apoptosis degree and functional deficits [9, 38-43]. Thus, all these findings could foster interest about research on apoptosis in $\mathrm{SIH}$ patients.

\section{Conclusions}

The novel finding of our study was that there is an association between high serum CCCK-18 levels and 30-day mortality in severe SIH patients.

\section{Abbreviations}

APACHE: Acute Physiology and Chronic Health Evaluation; CCCK: caspasecleaved cytokeratin; $\mathrm{FlO}_{2}$ : fraction inspired of oxygen; GCS: Glasgow Coma Scale; ICU: Intensive Care Unit; INR: international normalized ratio; ISS: Injury Severity Score; $\mathrm{PaO}_{2}$ : pressure of arterial oxygen.

\section{Authors' contributions}

LL conceived, designed and coordinated the study, participated in acquisition and interpretation of data, and drafted the manuscript. MMM, MA, LR, JSV, JJC, 
VGM participated in acquisition of data. APC participated in blood determination levels. AJ participated in the interpretation of data. All authors revised the manuscript critically for important intellectual content. All authors read and approved the final manuscript.

\section{Author details}

${ }^{1}$ Intensive Care Unit, Hospital Universitario de Canarias, Ofra, s/n, La Laguna, 38320 Santa Cruz de Tenerife, Spain. ${ }^{2}$ Intensive Care Unit, Hospital Universitario Nuestra Señora de Candelaria, Crta del Rosario s/n, 38010 Santa Cruz de Tenerife, Spain. ${ }^{3}$ Laboratory Department, Hospital Universitario de Canarias, Ofra, s/n, La Laguna, 38320 Santa Cruz de Tenerife, Spain. ${ }^{4}$ Intensive Care Unit, Hospital General La Palma, Buenavista de Arriba s/n, Breña Alta, 38713 La Palma, Spain. ${ }^{5}$ Intensive Care Unit, Hospital Clínico Universitario de Valencia, Avda. Blasco Ibáñez no 17-19, 46004 Valencia, Spain. ${ }^{6}$ Intensive Care Unit, Hospital Universitario Dr. Negrín, CIBERES, Barranco de la Ballena s/n, 35010 Las Palmas de Gran Canaria, Spain. ${ }^{7}$ Intensive Care Unit, Hospital Insular, Plaza Dr. Pasteur s/n, 35016 Las Palmas de Gran Canaria, Spain. ${ }^{8}$ Research Unit, Hospital Universitario de Canarias, Ofra, s/n, La Laguna, 38320 Santa Cruz de Tenerife, Spain. ${ }^{9}$ Department of Neurosurgery, Hospital Universitario de Canarias, Ofra, s/n, La Laguna, 38320 Santa Cruz de Tenerife, Spain.

\section{Acknowledgements}

Not applicable.

\section{Competing interests}

The authors declare that they have no competing interests.

\section{Availability of data and materials}

The datasets used and/or analysed during the current study are available from the corresponding author on reasonable request.

\section{Consent for publication}

Not applicable.

\section{Ethics approval and consent to participate}

This multicentre, observational and prospective study was carried in 6 Intensive Care Units from Spain after the Institutional Review Board approval of all participating hospitals and with the written consent of patient guardians. Participating hospitals were the following: $\mathrm{H}$. Clínico Universitario de Valencia (Valencia), H. Universitario Nuestra Señora de Candelaria (Tenerife), H. General de La Palma (La Palma), H. Universitario de Canarias (Tenerife), H. Insular (Gran Canaria), H. Universitario Dr. Negrín (Gran Canaria).

\section{Funding}

This study was supported by a grant from Grupo de Expertos Neurológicos de Canarias (GEN-Canarias. Santa Cruz de Tenerife. Spain), and by a grant from Instituto de Salud Carlos III (INT16/00165) (Madrid, Spain) co-financed with Fondo Europeo de Desarrollo Regional (FEDER). Fundings did not influence in the study design, the collection, analysis, and interpretation of data, the manuscript writing, and the decision to submit it for publication.

\section{Publisher's Note}

Springer Nature remains neutral with regard to jurisdictional claims in published maps and institutional affiliations.

Received: 5 December 2017 Accepted: 6 April 2018 Published online: 16 April 2018

\section{References}

1. Broderick J, Connolly S, Feldmann E, Hanley D, Kase C, Krieger D, Mayberg M, Morgenstern L, Ogilvy CS, Vespa P, Zuccarello M, American Heart Association; American Stroke Association Stroke Council; High Blood Pressure Research Council; Quality of Care and Outcomes in Research Interdisciplinary Working Group. Guidelines for the management of spontaneous intracerebral hemorrhage in adults: 2007 update: a guideline from the American Heart Association/American Stroke Association Stroke Council, High Blood Pressure Research Council, and the Quality of
Care and Outcomes in Research Interdisciplinary Working Group. Stroke. 2007;38:2001-23.

2. Morgenstern LB, Hemphill JC 3rd, Anderson C, Becker K, Broderick JP, Connolly ES Jr, Greenberg SM, Huang JN, MacDonald RL, Messé SR, Mitchell PH, Selim M, Tamargo RJ, American Heart Association Stroke Council and Council on Cardiovascular Nursing. Guidelines for the management of spontaneous intracerebral hemorrhage: a guideline for healthcare professionals from the American Heart Association/American Stroke Association. Stroke. 2010;41:2108-29.

3. Hemphill JC 3rd, Greenberg SM, Anderson CS, Becker K, Bendok BR, Cushman M, Fung GL, Goldstein JN, Macdonald RL, Mitchell PH, Scott PA, Selim MH, Woo D, American Heart Association Stroke Council; Council on Cardiovascular and Stroke Nursing; Council on Clinical Cardiology. Guidelines for the management of spontaneous intracerebral hemorrhage: a guideline for healthcare professionals from the American Heart Association/American Stroke Association. Stroke. 2015;46:2032-60.

4. Bobinger T, Burkardt $P$, Huttner HB, Manaenko A. Programmed cell death after intracerebral hemorrhage. Curr Neuropharmacol. 2017. https://doi. org/10.2174/1570159X15666170602112851.

5. Liao KH, Sung CW, Huang YN, Li WJ, Yu PC, Wang JY. Therapeutic potential of drugs targeting pathophysiology of intracerebral hemorrhage: from animal models to clinical applications. Curr Pharm Des. 2017;23:2212-25.

6. Salihu AT, Muthuraju S, Idris Z, Izaini Ghani AR, Abdullah JM. Functional outcome after intracerebral haemorrhage - a review of the potential role of antiapoptotic agents. Rev Neurosci. 2016;27:317-27.

7. Hwang BY, Appelboom G, Ayer A, Kellner CP, Kotchetkov IS, Gigante PR, Haque R, Kellner M, Connolly ES. Advances in neuroprotective strategies: potential therapies for intracerebral hemorrhage. Cerebrovasc Dis. 2011;31:211-22.

8. Nakashima K, Yamashita K, Uesugi S, Ito H. Temporal and spatial profile of apoptotic cell death in transient intracerebral mass lesion of the rat. $J$ Neurotrauma. 1999;16:143-51.

9. Matsushita K, Meng W, Wang X, Asahi M, Asahi K, Moskowitz MA, Lo EH. Evidence for apoptosis after intercerebral hemorrhage in rat striatum. J Cereb Blood Flow Metab. 2000;20:396-404.

10. Qureshi Al, Ling GS, Khan J, Suri MF, Miskolczi L, Guterman LR, Hopkins LN. Quantitative analysis of injured, necrotic, and apoptotic cells in a new experimental model of intracerebral hemorrhage. Crit Care Med. 2001;29:152-7.

11. Karwacki Z, Kowiański P, Dziewatkowski J, Domaradzka-Pytel B, Ludkiewcz B, Wójcik S, Narkiewicz O, Moryś J. Apoptosis in the course of experimental intracerebral haemorrhage in the rat. Folia Morphol (Warsz). 2005;64:248-52.

12. Wang YX, Yan A, Ma ZH, Wang Z, Zhang B, Ping JL, Zhu JS, Zhou Y, Dai L. Nuclear factor- $\mathrm{KB}$ and apoptosis in patients with intracerebral hemorrhage. J Clin Neurosci. 2011;18:1392-5.

13. Bao G, Han Y, Wang M, Xu G. Relationship between cellular apoptosis and the expression of p75 neurotrophin receptor and tyrosine kinase A receptor in tissue surrounding haematoma in intracerebral haemorrhage. J Int Med Res. 2011;39:150-60.

14. Zhang $X Q$, Zhang ZM, Yin XL, Zhang K, Cai H, Ling F. Exploring the optimal operation time for patients with hypertensive intracerebral hemorrhage: tracking the expression and progress of cell apoptosis of prehematomal brain tissues. Chin Med J (Engl). 2010;123:1246-50.

15. Wu CH, Ding XY, Wang HY, Ye XB, Huang SY, Huang AM, Li HZ, Wu SY, Yu $J$, Yan XH. Neural apoptosis and apoptosis-related genes in intracerebral hemorrhage patients. Zhonghua Yi Xue Za Zhi. 2006;86:3073-6.

16. Guo FQ, Li XJ, Chen LY, Yang H, Dai HY, Wei YS, Huang YL, Yang YS, Sun HB, XU YC, Yang ZL. Study of relationship between inflammatory response and apoptosis in perihematoma region inpatients with intracerebral hemorrhage. Zhongguo Wei Zhong Bing Ji Jiu Yi Xue. 2006; 18:290-3.

17. Zhu S, Tang Z, Guo S, Peng L, Fang S, Zhang S. Experimental study on the expression of HIF-1 alpha and its relationship to apoptosis in tissues around cerebral bleeding loci. J Huazhong Univ Sci Technol Med Sci. 2004;24:373-5.

18. Qureshi Al, Suri MF, Ostrow PT, Kim SH, Ali Z, Shatla AA, Guterman LR, Hopkins LN. Apoptosis as a form of cell death in intracerebral hemorrhage. Neurosurgery. 2003;52:1041-7.

19. Chu PG, Weiss LM. Keratin expression in human tissues and neoplasms. Histopathology. 2002:40:403-39. 
20. Caulín C, Salvesen GS, Oshima RG. Caspase cleavage of keratin 18 and reorganization of intermediate filaments during epithelial cell apoptosis. J Cell Biol. 1997;138:1379-94.

21. Roth GA, Krenn C, Brunner M, Moser B, Ploder M, Spittler A, Pelinka L, Sautner T, Wolner E, Boltz-Nitulescu G, Ankersmit HJ. Elevated serum levels of epithelial cell apoptosis-specific cytokeratin 18 neoepitope m30 in critically ill patients. Shock. 2004;22:218-20.

22. Moore DJ, Greystoke A, Butt F, Wurthner J, Growcott J, Hughes A, Dive C. A pilot study assessing the prognostic value of CK18 and nDNA biomarkers in severe sepsis patients. Clin Drug Investig. 2012;32:179-87.

23. Hofer S, Brenner T, Bopp C, Steppan J, Lichtenstern C, Weitz J, Bruckner T, Martin E, Hoffmann U, Weigand MA. Cell death serum biomarkers are early predictors for survival in severe septic patients with hepatic dysfunction. Crit Care. 2009;13:R93.

24. Lorente L, Martín MM, González-Rivero AF, Ferreres J, Solé-Violán J, Labarta L, Díaz C, Jiménez A, Borreguero-León JM. Serum levels of caspase-cleaved cytokeratin-18 and mortality are associated in severe septic patients: pilot study. PLoS ONE. 2014;9:e109618.

25. Lorente L, Martín MM, Pérez-Cejas A, López RO, Ferreres J, Solé-Violán J, Labarta L, Díaz C, Palmero S, Buitrago M, Jiménez A, Borreguero-León JM. Higher serum caspase-cleaved cytokeratin-18 levels during the first week of sepsis diagnosis in non-survivor patients. Clin Chem Lab Med. 2017;55:1621-9.

26. Bantel H, Lügering A, Heidemann J, Volkmann X, Poremba C, Strassburg CP, Manns MP, Schulze-Osthoff K. Detection of apoptotic caspase activation in sera from patients with chronic HCV infection is associated with fibrotic liver injury. Hepatology. 2004:40:1078-87.

27. Sgier C, Müllhaupt B, Gerlach T, Moradpour D, Negro F, Malé PJ, Heim MH, Malinverni R, Cerny A, Dufour JF. Effect of antiviral therapy on circulating cytokeratin-18 fragments in patients with chronic hepatitis C. J Viral Hepat. 2010;17:845-50.

28. Sumer S, Aktug Demir N, Kölgelier S, Cagkan Inkaya A, Arpaci A, Saltuk Demir L, Ural O. The clinical significance of serum apoptotic cytokeratin 18 neoepitope M30 (CK-18 M30) and matrix metalloproteinase 2 (MMP-2) levels in Chronic hepatitis B patients with cirrhosis. Hepat Mon. 2013;13:e10106.

29. Parfieniuk-Kowerda A, Lapinski TW, Rogalska-Plonska M, Swiderska M, Panasiuk A, Jaroszewicz J, Flisiak R. Serum cytochrome c and m30-neoepitope of cytokeratin-18 in chronic hepatitis C. Liver Int. 2014:34:544-50.

30. Lorente L, Rodriguez ST, Sanz P, Pérez-Cejas A, Padilla J, Díaz D, González A, Martín MM, Jiménez A, Barrera MA. Prognostic value of serum caspase-cleaved cytokeratin-18 levels before liver transplantation for one-year survival of patients with hepatocellular carcinoma. Int J Mol Sci. 2016;17:1524.

31. Ueno T, Toi M, Bivén K, Bando H, Ogawa T, Linder S. Measurement of an apoptotic product in the sera of breast cancer patients. Eur J Cancer. 2003;39:769-74
32. Greystoke A, O'Connor JP, Linton K, Taylor MB, Cummings J, Ward T, Maders F, Hughes A, Ranson M, Illidge TM, Radford J, Dive C. Assessment of circulating biomarkers for potential pharmacodynamic utility in patients with lymphoma. Br J Cancer. 2011;104:719-25.

33. Lorente L, Martín MM, González-Rivero AF, Argueso M, Ramos L, SoléViolán J, Cáceres JJ, Jiménez A, Borreguero-León JM. Serum levels of caspase-cleaved cytokeratin-18 in patients with severe traumatic brain injury are associated with mortality: a pilot study. PLoS ONE. 2015;10:e0121739.

34. Yuan ZG, Wang JL, Jin GL, Yu XB, Li JQ, Qiu TL, Dai RX. Serum caspasecleaved cytokeratin-18 levels and outcomes after aneurysmal subarachnoid hemorrhage. J Neurol Sci. 2015:359:298-304.

35. Gu SJ, Lu M, Xuan HF, Chen XZ, Dong WF, Yan XF, Si Y, Gao GL, Hu DX, Miao JQ. Predictive value of serum caspase-cleaved cytokeratin-18 concentrations after acute intracerebral hemorrhage. Clin Chim Acta. 2016;452:124-8.

36. Teasdale $G$, Jennett B. Assessment of coma and impaired consciousness. A practical scale. Lancet. 1974;2:81-4.

37. Knaus WA, Draper EA, Wagner DP, Zimmerman JE. APACHE II: a severity of disease classification system. Crit Care Med. 1985;13:818-29.

38. Jung KH, Chu K, Lee ST, Kim SJ, Song EC, Kim EH, Park DK, Sinn DI, Kim JM, Kim M, Roh JK. Blockade of AT1 receptor reduces apoptosis, inflammation, and oxidative stress innormotensive rats with intracerebral hemorrhage. J Pharmacol Exp Ther. 2007;322:1051-8.

39. Liu X, Yuan D, Nie X, Shen J, Yan Y, Zhang D, Gu J. BTEB2 prevents neuronal apoptosis via promoting bad phosphorylation in rat intracerebral hemorrhage model. J Mol Neurosci. 2015;55:206-16.

40. Kim SE, Ko IG, Shin MS, Kim CJ, Ko YG, Cho H. Neuroprotective effects of bovine colostrum on intracerebral hemorrhage-induced apoptotic neuronal cell death in rats. Neural Regen Res. 2012;7:1715-21.

41. Lee IN, Cheng WC, Chung CY, Lee MH, Lin MH, Kuo CH, Weng HH, Yang JT. Dexamethasone reduces brain cell apoptosis and inhibits inflammatory response in rats with intracerebral hemorrhage. J Neurosci Res. 2015;93:178-88.

42. Hu YY, Huang M, Dong XQ, Xu QP, Yu WH, Zhang ZY. Ginkgolide B reduces neuronal cell apoptosis in the hemorrhagic rat brain: possible involvement of Toll-like receptor 4/nuclear factor-kappa B pathway. J Ethnopharmacol. 2011;137:1462-8.

43. Rodrigues CM, Sola S, Nan Z, Castro RE, Ribeiro PS, Low WC, Steer CJ. Tauroursodeoxycholic acid reduces apoptosis and protects against neurological injury after acute hemorrhagic stroke in rats. Proc Natl Acad Sci U S A. 2003;100:6087-92.

Ready to submit your research? Choose BMC and benefit from

- fast, convenient online submission

- thorough peer review by experienced researchers in your field

- rapid publication on acceptance

- support for research data, including large and complex data types

- gold Open Access which fosters wider collaboration and increased citations

- maximum visibility for your research: over $100 \mathrm{M}$ website views per year

At BMC, research is always in progress.

Learn more biomedcentral.com/submissions 